\title{
Transparency in the Implementation of Good Corporate Governance in Indonesia Public Company
}

\author{
Hamzah $^{1}$, Muh Barid Nizarudin Wajdi ${ }^{2}$ \\ Law Faculty, Universitas Lampung, Indonesia ${ }^{1}$ \\ STAI Miftahul Ula Nganjuk, Indonesia ${ }^{2}$
}

$\left\{\right.$ baridnizar84@gmail. $\left.\mathrm{com}^{2}\right\}$

\begin{abstract}
The economic crisis has presented the fact of how vulnerable Indonesian companies are. The failure of the company to survive in the crisis due to bad corporate governance. The Board of Directors is the executive organ that determines the progress of the company. The shareholder is the party most concerned with the governance of the company. Good Corporate Governance is a policy that aims to strengthen the company. Transparency is a central principle in Good Corporate Governance. Transparency is used interchangeably for disclosure. Law no. 8 of 1995 Concerning Capital Market covers the principle of transparency through disclosure. Conversely, the Good Corporate Governance guidelines mention disclosure of information in transparency. The Financial Services Authority (OJK) still exercises its authority to enforce capital market laws. Every year, OJK impose administrative sanctions on companies that violate information disclosure. Administrative sanctions are aimed at building the compliance of public companies (issuers) and public companies
\end{abstract}

Keywords: OJK, Corporate Governance, Company

\section{Introduction}

The advancement of the company is based on how a company can understand the challenge, problem, and opportunity. All elements in the company work to achieve the company's goal, namely to achieve profit. The achievement of corporate goals is done by the company's executive organs. All actions in running the company. Actions with and different, intended for the benefit of the company[1].

The corporate law doctrine stated that shareholders are the owners of companies that need current and relevant information to the company's circumstances. Board of Directors has two duties, to carry out its duties solely because of the interests of the company. Professional attitude, knowledge, experience becomes capital for the directors to run the company[2].

Good Corporate Governance is a guideline to avoid failure to navigate a great crisis. There are five principles in Good Corporate Governance of Transparency, Accountability, Independence, Independence, and Fairness. It is a principle that is absent in the management of a company in Indonesia before it happens[3], [4].

Transparency regarding the quality of information as well as related to access to information to all interested parties in the company[5]. Once important, transparency for the company and stakeholders, so that it gets a position in the provisions of the law, although true 
transparency is one form of ethics[6]. Transparency is rapidly increasingly recognized as a key element in economic growth. Transparency bridges the information gap, the gap between directors and shareholders. Transparency is a form of ethical and responsible action of the Board of Directors to convey information to shareholders[7].

Transparency is realized through the delivery of mandatory information through the submission of periodic and incidental reports. Every year an open company or public company is required to submit annual reports to shareholders and capital market authorities. Every time an open company or public company is obliged to submit a report as soon as possible if there are changes or material facts regarding the company.

Good Corporate Governance (GCG) Principles are applied to all companies, but open companies have more reason to apply Good Corporate Governance principles. As an assumptive, public companies should be more stringent and sustainable with the principles of Good Corporate Governance. Public companies have an obligation to convey information to their shareholders periodically or incidental as regulated in the capital market regulation. Companies that conduct public offerings are subject to the provisions on information disclosure as set forth in the Capital Market Law Article 83[8]. This is the norm or ethic of Good Corporate Governance articulated in the legal provisions. The Financial Services Authority (OJK) makes guidelines regarding the implementation of the principle of information disclosure. Implementation of information disclosure must be ensured by OJK since the registration statement as stated by Law no. 8 of 1995 Concerning Capital Market Article 75 (1)[8].

\section{Literature review}

According to Sony Yuwono[9], Transparency has a meaning of openness in the process of planning, preparation, and implementation of the budget. In line with Mardiasmo[10], transparency is "Openness in the process of planning, drafting, and implementation of local budgets." Furthermore, EdahJubaedah[11] states that "Transparency is the principle to open up to the right of the people to gain access to correct, honest and non-discriminatory information about organizing the organization with due regard to the protection of the personal, group, and state privacy rights.[12]"

The Government of Indonesia, in this case the Minister of State-Owned Enterprises, means "Good Corporate Governance", is a process and structure used by SOE organs to enhance business success and corporate accountability in order to realize shareholder value in the long term and still pay attention to the interests of other stakeholders, invitations and ethical values.

In law enforcement in capital market activity, it is necessary for another law enforcement concept, which is meant in this paper is law enforcement in the sense of Law Enforcement. Joseph Golstein[13], distinguishes criminal law enforcement on three kinds: First, Total Enforcement, namely the scope of criminal law enforcement as formulated by substantive criminal law. This first law enforcement is not possible because law enforcement is strictly limited by criminal procedural law. In addition, the substantive criminal law itself has the possibility of setting limits. This restricted scope is called the area of no enforcement.

Second, Full Enforcement, which is Total Enforcement after deducting area of no enforcement, where law enforcers are expected to enforce the law maximally, but according to Goldstein it is difficult to achieve (not a realistic expectation), because of the limitations in the form of time, personal, tools of funds and so on which can lead to discretion. Third, Actual Enforcement, Actual Enforcement is only able to walk if, there is sufficient evidence. In other words, there must be an act, a doer, witness or other evidence, and a breach of the article. 
Sanction in Administrative Law is "a tool of public legal power that can be used by the government in reaction to non-compliance with the obligations contained in the norms of the Law of State Administration." Based on this definition there appear to be four elements of sanctions in the laws of state administration, namely the power tool (machtmiddelen ), public legal (publiekrechtlijke), used by the government (overheid), in reaction to non-compliance (reactive op niet-naleving). Types of Administrative Sanctions can be seen from the aspect of the target are:

- Reparatoir sanctions, meaning sanctions imposed in reaction to violations of norms, aimed at returning to the original state prior to the offense, eg bestuursdwang, dwangsom;

- Punitive Sanctions, meaning sanctions intended to impose penalties on a person, for example is in the form of administrative fines;

- Regressive sanctions, are sanctions imposed in response to non-compliance with the provisions contained in the published provisions.

\section{Method}

The research method used in this research is normative juridical research method. Normative juridical research is a study that refers to the legal norms contained in legislation and court decisions relating to the transfer of risk and responsibility of business actors in the perspective of consumer protection. In order to obtain accurate data, then the following steps are taken: First, the study of literature, the way taken is to read, study, cite, compare and connect the legal materials of legislation and literature, so as to become easy to process. Second, conduct interviews on parties related to the problems studied.

\section{Result and discussion}

\subsection{Transparency Concepts}

The Good Corporate Governance Principle is a code of conduct for corporate governance. As a legal entity, the company is the depersonalization of its founders to merge all its capital, whether by c money or non-money, to run the company. Transparency is the first principle in Good Corporate Governance. Conceptually, transparency is associated or identified with information disclosure. Both are used interchangeably for the same. Information disclosure and transparency can have different meanings. Transparency has 3 components, namely:

- Transparency of issuers through disclosure of information under national law by investors who have certain ownership limits.

- Transparency of issuers through disclosure of information under national law by intermediaries that have an effect on investors and who must respond to requests for information disclosure.

- Transparency to the general public, international regulatory bodies and law enforcement regarding company owners.

Furthermore, transparency is based on the public interest, in exchange for the assumed risk that there are people who run the company. The Board of Directors controls the information and is closer to the facts concerning the company. While shareholders give trust to the directors to run the company and with it the shareholders authorize the directors to run the company. Thus, there is a shareholder distance with important information pertaining to the 
company. The Board of Directors controls the information. The so-called agency problem, a condition where shareholders do not get important information related to the company because the directors failed to implement the delivery of information, either due to delays or due to the quality of the information.

Transparency is a Basic Principle in Good Corporate Governance principles. To maintain objectivity in running a business, the company must provide material and relevant information in a manner that is easily accessible and understood by stakeholders. Companies should take the initiative to disclose not only the problems required by legislation but also important for decision-making by shareholders, creditors, and other stakeholders.

If Good Corporate Governance principles use transparency terminology to mention at the same time information disclosure, capital market law instead uses the disclosure of information to mention transparency at the same time. Capital Market Law does not distinguish transparency from information disclosure[14]. The Law Number 8 Year 1995 on Capital Markets Article 1 point 25 states the Principle of Disclosure is a general guideline which requires Issuers, Public Companies and other Persons subject to this Act to inform the public in a timely manner all Material Information concerning its business or its effects which may effect on the decision of the investor to the said Securities and or the price of such Securities. The definition obtains a juridical substance in the same Law Stipulation in Article 86 paragraph (1) mentioning the Issuer whose Registration Statement has become effective or the Public Company shall submit periodic reports to Bapepam and publish the report to the public; and submit a report to Bapepam and announce to the public about material events that may affect the price of Securities no later than the end of the second (2) workday after the event[15].

The failure to submit material information under such provisions has resulted in legal consequences, namely the imposition of administrative sanctions for violations of this Act and its implementing regulations as stated in Law No. 8 Year 1995 on Capital Market Article 102. The Indonesian capital market regime uses administrative sanctions to build the compliance of issuers and public companies; and company managers. This is in line with Fox's view that "The purpose of punishment in any form is to build compliance and create a deterrent effect for the perpetrator and the parties, other parties. On the other hand, administrative sanctions in the form of fines have weaknesses in their application in the financial services sector. The Company may calculate the profit and loss of fines for the violations committed, considering the amount of money that can be made a limited penalty as stipulated by the provisions of the law. If so, the administrative penalty should be imposed in layers equivalent to the degree of error.

\subsection{Good Corporate Governance}

Good Corporate Governance is a guideline for directors and commissioners in running a company. The dynamics of the economy and business are sometimes negative and create crises. These guidelines are implemented to strengthen the company in times of trouble as the crisis arrives.

Historically, Indonesia has known the company since the Dutch colonial era when the VOC did business on Indonesian soil. Recorded 2,400 companies operating in Indonesia in 1914 , rising to 3,700 in 1920 , declining to 2,800 enterprises in 1930 , decreasing again to 2,200 in 1940. In the colonial period until before 1995, the company was governed in the Book of Commercial Law. Indonesia has legal provisions of the company since 1995. The Government of Indonesia enacted Law No. 1 Year 1995 about Limited Liability Company. With the 
enactment of Law No. 1 Year 1995, the provisions concerning companies in the Commercial Code are declared no longer valid. Since then, Law No. 1 Year 1995 on Limited Company becomes a provision for establishment, management, and closure of a company. Law No. 1 Year 1995 on Limited Liability Company is replaced by Law No. 40 Year 2007 on Limited Liability Company.

Company legal theory recognizes several theories. First, the theory of company establishment. This theory states that the formation of the company results from the delegation of power from the state to the community through the establishment of the firm with the firm or implicit monopoly power in a particular region, be it geographical or economic territory. This is a preliminary corporate theory prevailing around the 16th century.

The second theory is a trust theory that views the company as a separate individual from its members, thus implying fiduciary duties and trusts in the perspective of mercantilism. The company runs its business in the interest of the state. The Director obtains the authority derived from the grant of the state. The privatization of SOEs causes the shift of the state as shareholders to individual persons as shareholders. In this context, the company is run to maximize shareholder prosperity. A shareholder is everything for the company (shareholder primacy). The third theory is the nexus theory of contract. This theory is totally different from the theory of founding and the theory of belief. According to this theory, the employer provides the worker; the creditor provides the capital (debt), the shareholder provides equity capital and assumes the risk of loss and monitors the performance of the management (the commissioners), the management monitors the performance of employees and coordinates the activities of the company. The company consists of various agreements and agencies, not fiduciary duties.

The theory of trust gives birth to good corporate governance (prudent and good) in which the application of information disclosure to shareholders is the elaboration. The management of the company submitted to the directors implies the distance between the shareholders and the board of directors. The Board of Directors has important information about the latest company. The principle of openness or transparency is a bridge to connect shareholders with companies, in this case, directors. Shareholders give part of their authority to the Board of Directors, namely the authority to run the company daily. Instead, the Board of Directors notes that running a company is intended to maximize shareholder wealth.

Structurally, companies in Indonesia consist of Directors, Commissioners, and Shareholders. The Board of Directors is a party to be given the trust and authority to run the company, including representing the company in front and outside the court. Commissioners are parties authorized to supervise the company's operations. A shareholder is the holder of any authority not granted to the Board of Directors or Commissioners. A shareholder is the owner of the company. The guidelines of the Board of Directors and Commissioners to run the company are the Company's Articles of Association and Household Affairs, Law no. 1 of 1995 on Limited Liability Companies and other related provisions and relevant to the management of the company.

With a two-tier system, the Commissioner performs its function as a party overseeing the company from management that does not attach importance to the shareholder's welfare. The implementation of Good Corporate Governance principles is more suitable to be done on enterprise systems that embrace the single-tier system. Because, indeed, the Commissioner can become an extension of shareholders to maintain the continuity of the company as a healthy and strong business entity. With the principles of Good Corporate Governance and with a two-tier system in the organizational structure of the company, the management of Indonesian companies, especially issuers and public companies should work well. 
With any system, the management of the company is aimed at the interests of shareholders. The progressive retreat of the company is the center of attention and interests of shareholders. Shareholders have the right to know the important information related to the company. The Law No. 8 Year 1995 on Capital Market Article 85 states the obligation to carry out information disclosure which is regulated in the provisions of Capital Market Supervisory Agency (Bapepam), now become The Financial Services Authority (OJK). The provisions are further stipulated in Bapepam-LK Regulation no. X.K.1. About Information Disclosure Should Be Announced to Public. OJK also requires Directors and Commissioners to execute disclosure of information for certain shareholders in Bapepam-LK Regulation no. X.M. 1. regarding Changes in Share Ownership of the Company.

In the process of bankruptcy, the Issuers or Issuers of Public Companies must implement the principles of information disclosure as stipulated in Bapepam-LK Regulation no. X. K. 5 On Information Disclosure to Issuers or Public Companies Invoked for Bankruptcy Statement. Disclosure of information and transparency remains the responsibility of the Board of Directors or Public Companies undergoing bankruptcy proceedings.

Transparency is a principle of public interest, in exchange for public assumptions regarding risks arising from persons acting through company vehicles. Implementation of the principle of transparency is a necessity and must be attributed to the large number and spread of shareholders of the company. Implementation of the principle of transparency can reach all shareholders through mass media and internet-based media.

\subsection{Law Enforcement Against Violations}

Implementation of the principle of information disclosure into the realm of OJK since submission of the registration statement as regulated in the provisions of Law no. 8 of 1995 Concerning Capital Markets Article 75. The violation of the provisions concerning the implementation of the principle of information disclosure is regulated in the provisions of Law no. 8 the Year 1995 on Capital Market Article 100 and Article 102.

In 2013 there were 19 issuers violating capital market regulations, but none of them violated the disclosure requirements. In 2014, OJK Commissioner Nurhaida explained that OJK had imposed 267 administrative sanctions in the form of fines to some issuers. Such penalties include delays in the submission of periodic reports, delays in report submission in addition to periodic reports, as well as delays in disclosure announcements. The total value of the administrative penalty of the fine reaches a total fine of $\mathrm{Rp} 3.399$ Billion. The number of fines did not provide a deterrent effect.

In 2015, OJK imposed administrative sanctions in the form of fines of 386 resulting from violations with delays in the submission of periodic reports, delays in report submission in addition to periodic reports, delays in disclosure announcements, and other violations of capital market provisions.

By 2016, OJK still finds information disclosure violations in a set of violations of capital market provisions. OJK impose an administrative sanction of 319 with a value of Rp3,275,400,000.00 (three billion two hundred seventy-five million and four hundred thousand rupiahs) is levied on violations in the form of late submission of periodic reports, delays in report submission in addition to periodic reports, and delays in disclosure of information. 


\section{Conclusion}

Transparency is a central principle of the Good Corporate Governance Principles covered by Law No. 1 Year 1995 on Limited Liability Company then replaced by Law No. 40 Year 2007 in the obligations of the Board of Directors. The principle of transparency is then contained in the provisions of Law No. 8 Year 1995 on Capital Market and Bapepam-LK Regulation on Information Transparency.

Violations of disclosure provisions still occur in the capital market, but not in large numbers. OJK and IDX impose administrative sanctions to control the violation of information disclosure. The sanctions are intended to build the compliance of the issuer or public company to run the company in accordance with the provisions of capital market law and Good Corporate Governance.

\section{References}

[1] M. S. Islam and S. A. F. Afroz, "Factor Affecting Organizational Citizenship Behaviour of Corporate Sector in Bangladesh," Organ, vol. 9, no. 1, 2016.

[2] C. K. Low, "A road map for corporate governance in East Asia," Nw. J. Int'l L. Bus., vol. 25 , p. 165, 2004.

[3] R. D. Retno and D. Priantinah, "Pengaruh good corporate governance dan pengungkapan corporate social responsibility terhadap nilai perusahaan (studi empiris pada perusahaan yang terdaftar di Bursa Efek Indonesia periode 2007-2010)," Nominal, Barom. Ris. Akunt. dan Manaj., vol. 1, no. 2, 2012.

[4] D. Prima and R. Pratiwi, "Pengaruh Good Corporate Governance Terhadap Agresivitas Pajak Dimediasi oleh Earnings Management Pada Perusahaan Yang Terdaftar di IICG."

[5] A. Lakhani, "Imposing Company Ownership Transparency Requirements: Opportunities for Effective Governance of Equity Capital Markets or Constraints on Corporate Performance," Chi.-Kent J. Int'l Comp. L., vol. 16, p. 122, 2016.

[6] I. H. Y. Chiu, "Reviving shareholder stewardship: critically examining the impact of corporate transparency reforms in the UK," Del. J. Corp. L., vol. 38, p. 983, 2013.

[7] J. Gandz and F. G. Bird, "The ethics of empowerment," J. Bus. Ethics, vol. 15, no. 4, pp. 383-392, 1996.

[8] J. Ginting, Hukum perseroan terbatas: (UU no. 40 tahun 2007). Citra Aditya Bakti, 2007.

[9] S. Yuwono, D. C. Utomo, and H. S. Zein, Memahami APBD dan Permasalahannya (Panduan Pengelolaan Keuangan Daerah). Malang: Bayumedia, 2008.

[10] D. Mardiasmo, P. H. Barnes, and Y. Sakurai, "Implementation of good governance by regional governments in Indonesia: the challenges," in Contemporary Issues in Public Management: The Twelfth Annual Conference of the International Research Society for Public Management (IRSPM XII), 2008.

[11] E. Jubaedah, N. Lili, and H. Faozan, "Model Pengukuran Pelaksanaan Good Governance di Pemerintah Daerah Kabupaten/kota.” Bandung: PKP2A I LAN, 2008.

[12] D. Mardiasmo, S. Tywoniak, K. A. Brown, and J. Burgess, "Asset management and governance: Analysing vehicle fleets in asset-intensive organisations," in Contemporary Issues in Public Management: The Twelfth Annual Conference of the International Research Society for Public Management (IRSPM XII), 2008. 
[13] J. Goldstein, A. M. Dershowitz, R. D. Schwartz, and R. C. Donnelly, Criminal law: Theory and process. Free Press New York, 1974.

[14] Presiden Republik Indonesia, Undang-Undang Nomor 8 Tahun 1995 Indonesia, Undang-Undang Tentang Pasar Modal. 1995.

[15] L. K. Bapepam, "Keputusan Ketua Badan Pengawas Pasar Modal dan Lembaga Keuangan Nomor: Kep-36.” PMK, 2003. 